\title{
PELATIHAN DAN PENDAMPINGAN PENYUSUNAN RPP BERMUATAN KEBUDAYAAN LOKAL DAN PENDIDIKAN KARAKTER BANGSA UNTUK GURU-GURU SEKOLAH DASAR DI GUGUS II KECAMATAN TEJAKULA
}

\author{
oleh, \\ Putu Nanci Riastini \\ Fakultas Ilmu Pendidikan \\ Universitas Pendidikan Ganesha
}

\begin{abstract}
ABSTRAK
Tujuan pengabdian kepada masyarakat ini adalah untuk meningkatkan kemampuan guru-guru sekolah dasar di Gugus II Kecamatan Tejakula dalam penyusunan perangkat pembelajaran bermuatan kebudayaan lokal untuk pendidikan karakter bangsa melalui kegiatan pelatihan dan pendampingan dan untuk meningkatkan keterampilan guru-guru sekolah dasar di Gugus II Kecamatan Tejakula dalam mengimplementasikan perangkat pembelajaran bermuatan kebudayaan lokal untuk pendidikan karakter bangsa melalui kegiatan pendampingan. Kegiatan-kegiatan yang dilakukan adalah pelatihan penyusunan perangkat pembelajaran berbasis kebudayaan lokal untuk pendidikan karakter bangsa bagi guru-guru Gugus II Kecamatan Tejakula, dan pendampingan yang dilakukan secara bertahap dan berkelanjutan. Metode-metode yang digunakan adalah metode pelatihan dan metode pembinaan serta pendampingan. Hasil kegiatan ini adalah 1) terjadinya peningkatan kemampuan guru-guru sekolah dasar di Gugus II Kecamatan Tejakula dalam penyusunan perangkat pembelajaran bermuatan kebudayaan lokal untuk pendidikan karakter bangsa setelah diberikan pelatihan dan pendampingan. Persentase keberhasilan kegiatan adalah 90\%, dan 2) terjadinya peningkatan keterampilan guruguru sekolah dasar di Gugus II Kecamatan Tejakula dalam mengimplementasikan perangkat pembelajaran bermuatan kebudayaan lokal untuk pendidikan karakter bangsa setelah diberikan pendampingan. Persentase keberhasilan kegiatan adalah $90 \%$.
\end{abstract}

Kata-kata kunci: kebudayaan lokal, karakter bangsa

\begin{abstract}
The aims of the community services were to increase the ability of teacher in Gugus II Kecamatan Tejakula to arrange lesson plan with local culture for character education through drill and peer teaching and to increase the skill of teacher in Gugus II Kecamatan Tejakula to do the lesson plan through peer teaching. All kinds of works
\end{abstract}


were drill of lesson plan arrangement with local culture for character education and peer teaching step by step and continue. The methods were drill method and peer teaching. The results are 1) there is $90 \%$ raising ability of teacher of Gugus II Kecamatan Tejakula to arrange lesson plan with local culture for character education and 2) there is $90 \%$ raising skill to do the lesson plan.

Keywords: local culture, nationality character

\section{Pendahuluan}

Pembelajaran berbasis kearifan lokal menjadi salah satu ciri-ciri paradigma baru pendidikan nasional yang telah diamanatkan dalam UU RI No. 20 Tahun 2003. Pada BAB X pasal 36 ayat 2 dituliskan bahwa "Kurikulum pada semua jenjang dan jenis pendidikan dikembangkan dengan prinsip diversifikasi sesuai dengan satuan pendidikan, potensi daerah, dan peserta didik". Dukungan terhadap pembelajaran berbasis kearifan lokal juga tampak pada pasal 37 ayat 1 butir $\mathrm{j}$, yang menyatakan bahwa "kurikulum pendidikan dasar dan menengah wajib memuat muatan lokal". Berdasarkan pernyataan-pernyataan tersebut, mengisyaratkan bahwa pembelajaran memang sangat perlu dikaitkan dengan kearifan lokal sebagai bentuk amanat desentralisasi pendidikan. Pendidikan merupakan sebuah proses penanaman nilai-nilai luhur, yang salah satunya bersumber dari kearifan lokal. Nilai-nilai yang telah diwariskan secara turun temurun tersebut sangat sarat dengan nilai-nilai luhur. Nilainilai inilah yang berfungsi untuk membentuk karakter anak bangsa yang berahlak mulia. Jika anak telah berkarakter mulia maka mereka akan berprilaku sesuai norma dan mampu menyaring kebudayaan asing yang masuk ke Indonesia.

Namun sayangnya, generasi muda bangsa Indonesia saat ini tidak memiliki kemampuan menyaring kebudayaan asing yang masuk ke Indonesia. Perkembangan peradaban menyeret mereka untuk tidak lagi mengenal budaya nenek moyangnya, bahkan mengalami kebanjiran budaya asing pada dirinya, Akibatnya, mereka mengalami kebingungan dengan budayanya sendiri maupun budaya baru yang membanjirinya. Hal inilah yang menjadi penyebab lunturnya karakter bangsa pada generasi muda, seperti budaya gotong royong, ramah, sopan santun, berbudi pekerti luhur, dan religius. 
Berdasarkan kenyataan tersebut, pembentukan karakter anak harus dilakukan sejak dini melalui pendidikan karakter, baik di lingkungan keluarga, masyarakat, maupun lingkungan sekolah. Di lingkungan sekolah, guru menjadi pelaku penting di sekolah dalam pembentukan karakter anak didiknya. Begitu pentingnya tugas yang diemban guru untuk membentuk karakter anak didiknya, maka guru harus meningkatkan kompetensi yang dimilikinya. Kompetensi yang dimaksud tidak hanya kompetensi kepribadian, sosial, maupun professional yang harus menjadi panutan bagi anak didik, tetapi kompetensi pedagogiknya pula dalam mengelola pembelajaran untuk pembentukan karakter. Guru harus mampu menggali dan menggunakan potensi-potensi lokal untuk pendidikan karakter bangsa dalam pembelajaran di sekolah. Jika kompetensi guru ini telah dikuasai, maka pembentukan karakter bangsa pada anak didik yang bersumber dari kearifan lokal akan dapat tercapai.

Kecamatan Tejakula memiliki beberapa gugus sekolah dasar, yang salah satunya adalah gugus II Kecamatan Tejakula. Gugus II Kecamatan Tejakula terdiri dari 9 sekolah yang ada di daerah Penuktukan dan Les, 4 sekolah ada di desa Penuktukan dan 5 sekolah ada di desa Les. Jumlah guru yang sudah PNS di gugus tersebut adalah 45 orang, yang mana $90 \%$ dari guru-guru di sekolah tersebut telah berpendidikan S1. Mereka berusia sekitar 20-50 tahun dengan tempat tinggal di daerah Les dan Penuktukan (Data Gugus II Kecamatan Tejakula). Jauhnya tempat tinggal dari pusat kabupaten menyebabkan arus informasi tidak terlalu cepat sampai di sekolah. Beberapa ketertinggalan yang disampaikan oleh guru-guru, diantaranya kemajuan komputer dan internet, perkembangan-perkembangan informasi pembelajaran, termasuk perangkat pembelajaran bermuatan kearifan lokal ataupun pendidikan karakter bangsa. Mereka mengakui hanya menulis karakter bangsa dalam perangkat pembelajaran, namun belum dapat merealisasikannya. Mereka juga kebingungan untuk memilih, menggunakan, dan mengimplementasikan hal-hal di daerah sekitar siswa untuk menanamkan nilai-nilai karakter yang ditulis, padahal banyak potensi kebudayaan lokal yang ada di Tejakula.

Kecamatan Tejakula berada di wilayah timur kabupaten Buleleng, sekitar 45 km dari pusat kota Buleleng. Daerah ini memiliki banyak potensi daerah yang sangat cocok untuk diintegrasikan dalam pembelajaran untuk pendidikan karakter bangsa. Sebagai contoh, di desa Sembiran masih mempertahankan sisi kehidupan upacara dan tatanan 
perkampungan tertua abad Megalithic walaupun arus perkembangan teknologi telah membanjiri wilayah tersebut. Berdasarkan hal tersebut, terlihat bahwa masih tampak jelas pengamalan karakter bangsa yang berupa nilai religius, disiplin, tanggung jawab, dan cinta terhadap lingkungan. Kearifan lokal yang memuat karakter bangsa seperti itu patut dikembangkan dalam pembelajaran, terutama di sekolah dasar.

Rendahnya pemahaman para guru tentang perangkat pembelajaran bermuatan kearifan lokal untuk pendidikan karakter bangsa tidak sepenuhnya kesalahan para guru. Faktor lain yang juga menjadi penyebab adalah kegiatan pengarahan yang diberikan belum ada yang berkaitan dengan kesulitan yang dialami. Pelatihan-pelatihan yang pernah diberikan terbatas pada strategi pembelajaran IPA, strategi pembelajaran Matematika, dan pembelajaran tematik. Akibatnya, mereka merasa tidak mendapatkan jawaban atas pertanyaan-pertanyaan tentang perangkat pembelajaran bermuatan kearifan lokal untuk pendidikan karakter bangsa. Permasalahan-permasalahan tersebut membuat mereka berharap begitu besar untuk mendapatkan kegiatan pembekalan atau sejenisnya untuk mengatasi ketidakpahamannya (hasil wawancara terhadap beberapa guru, Agustus 2012).

Berdasarkan uraian di atas, para guru sekolah dasar di gugus II Kecamatan Tejakula memerlukan sebuah pelatihan dan pendampingan secara berkesinambungan untuk mengatasi permasalahan mereka. Hal ini sangat perlu dilakukan agar para guru dapat memenuhi tugas dan tanggungjawabnya untuk mencerdaskan anak bangsa sesuai tuntutan yang ada pada UU No. 20 Tahun 2003. Kegiatan pelatihan dan pendampingan dalam penyusunan dan implementasi ini juga bertujuan agar guru-guru gugus II Tejakula dapat memahami, menyusun, dan mengimplementasikannya secara mandiri. Dengan demikian, kegiatan pelatihan dan pendampingan ini akan dapat meningkatkan kompetensi seorang guru dan terbentuknya karakter bangsa pada diri siswa.

\section{Metode Pelaksanaan Kegiatan}

Untuk mengatasi permasalahan yang dihadapi, maka dilakukan beberapa kegiatan. Kegiatan-kegiatan yang dilakukan adalah pelatihan penyusunan perangkat pembelajaran berbasis kebudayaan lokal untuk pendidikan karakter bangsa bagi guru-guru Gugus II Kecamatan Tejakula, dan pendampingan yang dilakukan secara bertahap dan 
berkelanjutan. Metode pelatihan digunakan untuk melatih mitra dalam menyusun perangkat pembelajaran berbasis kebudayaan lokal untuk pendidikan karakter bangsa. Selanjutnya, pendampingan digunakan sebagai langkah monitoring pasca pelatihan dan mendampingi kegiatan agar dapat berlanjut.

Peningkatan pemahaman, kemampuan, dan keterampilan guru-guru sekolah dasar Gugus II Kecamatan Tejakula untuk menyusun dan mengimplementasikan perangkat pembelajaran bermuatan kebudayaan lokal untuk pendidikan karakter bangsa dilakukan dengan metode-metode berikut. (1) Metode ceramah, diskusi, tanya jawab, dan praktik digunakan dalam kegiatan pelatihan penyusunan perangkat pembelajaran bermuatan kebudayaan lokal untuk pendidikan karakter bangsa. Metode-metode ini digunakan untuk meningkatkan pemahaman dan kemampuan para guru tentang penyusunan perangkat pembelajaran bermuatan kebudayaan lokal untuk pendidikan karakter bangsa. (2) Metode drill digunakan dalam proses pendampingan penyusunan dan implementasi perangkat pembelajaran bermuatan kebudayaan lokal untuk pendidikan karakter bangsa.

\section{Hasil dan Pembahasan}

Kegiatan pengabdian kepada masyarakat dalam bentuk Pelatihan dan Pendampingan Penyusunan RPP Bermuatan Kebudayaan Lokal dan Pendidikan Karakter Bangsa Untuk Guru-Guru Sekolah Dasar di Gugus II Kecamatan Tejakula dilaksanakan dalam 2 jenis kegiatan. Berdasarkan hasil observasi penyusunan rancangan RPP, 90\% peserta memahami langkah-langkah penyusunan RPP bermuatan kebudayaan lokal untuk pendidikan karakter bangsa. Peserta juga menyatakan bahwa penyajian materi dari tim pelaksana sangat baik dan jelas. Mengacu pada kegiatan pendampingan, 90\% peserta telah menghasilkan RPP bermuatan kebudayaan lokal untuk pendidikan karakter bangsa.

Berdasarkan keberhasilan kegiatan pengabdian kepada masyarakat yang telah dicapai, namun masih terdapat beberapa hal yang masih perlu mendapat perhatian. Beberapa hal tersebut adalah kesadaran dan motivasi para guru untuk menyelesaikan tugas dengan baik, keterampilan penggunaan Microsoft Word, dan kemampuan menyusun instrumen penilaian. Upaya perbaikan yang dapat dilakukan adalah pelatihan keterampilan pengunaan Microsoft Word, pelatihan penyusunan instrumen penilaian, 
dan mendatangkan motivator untuk memberikan arahan pada para guru agar motivasi kerja mereka meningkat,

\section{Penutup}

Kesimpulan kegiatan pengabdian kepada masyarakat ini adalah 1) terjadinya peningkatan kemampuan guru-guru sekolah dasar di Gugus II Kecamatan Tejakula dalam penyusunan perangkat pembelajaran bermuatan kebudayaan lokal untuk pendidikan karakter bangsa setelah diberikan pelatihan dan pendampingan. Persentase keberhasilan kegiatan adalah $90 \%$, dan 2) terjadinya peningkatan keterampilan guruguru sekolah dasar di Gugus II Kecamatan Tejakula dalam mengimplementasikan perangkat pembelajaran bermuatan kebudayaan lokal untuk pendidikan karakter bangsa setelah diberikan pendampingan. Persentase keberhasilan kegiatan adalah 90\%.

\section{DAFTAR PUSTAKA}

Buku Data Personalia Gugus II Kecamatan Tejakula UU No. 20 Tahun 2003. www.mandikdasmen.depdiknas.go.id (diakses tanggal 20 Agustus 2012) 